Troubling Freedom 



\section{Troubling Freedom}

ANTIGUA AND THE AFTERMATH

OF BRITISH EMANCIPATION

\section{Natasha Lightfoot}

DUKE UNIVERSITY PRESS

Durham and London 2015 
() 2015 Duke University Press

All rights reserved

Printed in the United States

of America on acid-free paper $\infty$

Typeset in Quadraat by Westchester Publishing Services

Library of Congress Cataloging-in-Publication Data

Lightfoot, Natasha, [date] author.

Troubling freedom : Antigua and the aftermath of

British emancipation / Natasha Lightfoot.

pages $\mathrm{cm}$

Includes bibliographical references and index.

ISBN 978-o-8223-5975-3 (hardcover : alk. paper)

ISBN 978-o-8223-6007-o (pbk. : alk. paper)

ISBN 978-o-8223-7505-o (e-book)

I. Slaves - Emancipation-Antigua and Barbuda-Antigua.

2. Slaves-Emancipation-Colonies-Great Britain.

3. Antigua-Race relations-History. I. Title.

F2O35.L54 2015

$305.800972974-\mathrm{dc23} 201502093 \mathrm{I}$

Cover art: Moravian Church Mission, St. John's Street (ca. 1830). Aquatint by Johann Stobwasser, Ansichten von Missions-Niederlassungen der Evangelishen Bruder-Gemeinde

(Basle, n.d.). Courtesy of the John Carter Brown Library at Brown University. 
TO THE PEOPLE OF ANTIGUA \& BARBUDA \& FOR MY SONS 
